\title{
ÉTREND-KIEGÉSZÍTŐK SZÍNÉNEK, ÍZÉNEK ÉS FORMÁJÁNAK HATÁSA FIATAL VÁSÁRLÓKRA
}

\author{
Rafael Bence
}

\begin{abstract}
Absztrakt: Az étrend-kiegészítők piaca jelentős szegmenst képvisel a patikák és más kereskedelmi egységek forgalmában. Kérdőíves felmérést végeztem fiatal vásárlók körében a színek, ízek, formák szerepének és jelentőségének megismerése céljából. Felállított hipotézisek alátámasztásával vagy elutasításával mutatom be vizsgálati eredményeimet és fogalmazom meg következtetéseimet, javaslataimat a vizsgálatom folytatásához, egy versenyképes termékcsoport kifejlesztése érdekében.
\end{abstract}

\begin{abstract}
The dietary supplements market represents an important segment of pharmacies and other commercial traffic units. I carried out a questionnaire survey among young buyers to learn about colours, flavours, shapes the role and significance. I present the test results have established assumptions underpinning or rejecting and formulate my conclusions, my suggestions to continue my research, to develop a competitive product group.
\end{abstract}

Kulcsszavak: étrend-kiegészítő, fiatal vásárlók, QBD, forma és hatás, kérdőíves felmérés

Keywords: dietary supplement, young customers, QBD, form and impact, survey

\section{Bevezetés}

Napjaink étrend-kiegészítő piaca óriási számban és dinamikus növekedéssel kínálja termékeit, gyakran egymás termékét másolva. A szín, az íz és a forma jelentősen motiválhatja vagy módosíthatja a vásárlási szándékot, alakíthatja a vásárlói szokásokat. Olyan kapcsolatok alakulhatnak ki termékek és vásárlóik, fogyasztóik között, amelyek mélyen berögződnek és - akár - egyfajta dependenciát is okozhatnak. A hatások - gyakran - nem azonnal jelentkeznek, melyek lehetnek a testi és lelki egészséget támogatók, de az ellentétére is találni példát. Különösen érdekes a középiskolás korosztály vizsgálata és véleményének megismerése, akik életkorukból adódóan - ekkor válnak önálló döntést hozó vásárlókká, törvényileg elérhetővé válik számukra a gyógyszerek megvásárlása is.

\section{Szakirodalmi áttekintés}

A Quality by Design a minőségi célok, a vásárlók és szükségleteik feltárásával kezdődik. Ez felállítja a célcsoportot és az igazán fontos szempontokat a minőségtervezésben. Igazán fontos szempontok azok, melyekkel a vásárlók foglalkoznak és amelyekért a jövőben hajlandók fizetni a termékeinkért. A termék és a gyártási folyamat tervezés együtt hajtja a minőségi teljesítményt. (Fraser, 2012) Fontos tehát, hogy a kutatás és a piaci elvárások egyre közelebb kerüljenek egymáshoz, melynek egyik eleme, hogy a hatósági igények már a kutatás fázisaiban is jelen legyenek. A kritikus minőségi paraméter („Critical Quality Attribute” CQA) a kimenő anyag - ideértve a kész terméket is - olyan fizikai, kémiai, biológiai vagy mikrobiológiai sajátsága vagy jellegzetessége, melynek egy meghatározott tartományba, határba vagy eloszlásba kell esnie, hogy biztosítsuk a termék minőségét. A termék minőségi jellegzetességei lehetnek az azonosíthatósága, a vizsgálata, a hatóanyag egységessége, az összetevők homogenitása, a 
melléktermékei, a maradék oldószere, a hatóanyag felszabadulása vagy kioldódása, a nedvességtartalma, a mikrobiológiai szennyezői, illetve a fizikai tulajdonságai úgy, mint a szín, a forma, a méret, az íz és illat, a bevágás mintája, a szilárdsága. Ezek a paraméterek lehetnek kritikusak vagy nem kritikusak. (Yu et al., 2014) A CQA-k meghatározása, kiválasztása nagy körültekintést és tudást, tapasztalatot igényel (előzetes kutatás eredményeinek ismerete), mert minden esetben másmás paraméter lehet kritikus hatással bíró. (Pallagi et al., 2015) Ennek megfelelően a CQA függ a gyógyszerformától és annak elvárt jellemzőitől, a gyártási folyamattól, az anyagoktól és minden esetben egyedi megfontolást kíván. (Charoo et al., 2012) Az általunk vizsgált kategóriát a 37/2004-es ESZCSM rendelet definiálja, meghatározva a gyógyszerformákat, melyeket használhatunk: „A hagyományos étrend kiegészítését szolgáló olyan élelmiszer, amely koncentrált formában tartalmaz tápanyagokat vagy egyéb táplálkozási vagy élettani hatással rendelkező anyagokat, egyenként vagy kombináltan; adagolt vagy adagolható formában kerül forgalomba (például kapszula, pasztilla, tabletta, port tartalmazó tasak, adagolható por, ampulla, csepegtetős üveg vagy más hasonló por-, illetve folyadékforma, amely alkalmas kis mennyiség adagolására)." (37/2004. (IV. 26.) ESZCSM rendelet az étrendkiegészítőkről, 2017)

\section{Vizsgálat módszerei, hipotézisek}

Jelen tanulmányban bemutatott kérdőíves felmérésem egy nagyobb vizsgálat részét képezi, amely szakdolgozatom témájául szolgál. Gyógyszerész hallgatóként fontosnak tartom, hogy a vény nélkül vásárolható termékek esetében a fogyasztók tisztában legyenek azzal, hogy a gyógyszernek nem minősülő étrend-kiegészítők esetében is fennállhat kockázat az értelmetlen, túlzott hatóanyag bevitelére és az esetleges inkompatibilitásokra már korábban jól gyógyszerelt betegségeknél. Ezért vélem fontosnak, hogy fejlödjön a fogyasztói tudatosság. Tekintettel arra, hogy itt egy részterület feldolgozása történik, elsődleges célom a koncepció meghatározása, illetve a kérdőív struktúrájának, kérdéseinek tesztelése. A felmérés nem tekinthető reprezentatívnak, a vizsgálati minta száma is alacsony ( $\mathrm{N}=25$ fö), viszont elöre vetíthető, hogy több kérdésre adott válasz így is egyfelé mutat, amely következtetések levonására ad feljogosítást. A kérdőíves felmérés 2018 februárjában történt egy Szegedhez közeli település középiskolájában. A különböző lakóhelyü és életkorú megkérdezettek önkéntesen adtak választ a kérdőívben szereplő 17 kérdésre, melyből 2 vonatkozott a kitöltő személyére, a további 15 pedig a vizsgált tartalomra. A kérdések sokszínüségét és változatosságát biztosította, hogy az egyszeres feleletválasztós mellett voltak több válaszlehetőség megjelölését biztosító zárt kérdések, valamint skálával minősíthető részek is. A válaszadó kreativitását nyílt kérdések (rajzolható és leírható) válaszlehetőségek biztosították. A kérdőív utolsó harmadában a válaszadó - korábbi, egyfajta tervező munkáját - választható forma és szín opciók kiválasztásával segítettem, melyek rávilágítottak a szín és forma kapcsán fellelhető kapcsolatokra, a elörevetített hatásokra.

A témával kapcsolatosan több hipotézist állítottam fel: 1. hipotézis. A vizsgált középiskolások tudatában keverednek a nem vényköteles gyógyszer és étrend- 
kiegészítő kategóriák, ismeretük felületes. 2. hipotézis. Az étrend-kiegészítők vásárlása kapcsán a fiatal fogyasztók esetében termék színe, íze és formája legalább olyan fontos, mint a hatóanyag tartalmuk vagy áruk. 3. hipotézis. A legkedveltebb gyógyszerforma a tabletta.

\section{Eredmények és értékelésük}

A kérdöívet 9 lány és 16 fiú töltötte ki. A nemek között ilyen alacsony elemszám mellett nem mutatható ki szignifikáns különbség az egyes kérdésekre adott válaszaik alapján. A válaszadók 92\%-a állította, hogy ismeri a különbséget gyógyszer és étrend-kiegészítő között. Az általuk írt válaszok alapján azonban kiderül, hogy a gyógyszerek preventív célú hasznosíthatóságát senki nem vette figyelembe, csak a betegség kezelés szerepelt a definícióik között. Majd hat darab termék közül, négy vény nélkül kapható gyógyszer (analgeticum, antacidum, immunerősítő, vitamin) és kettő étrend-kiegészítő multivitamin körül kellett eldönteni melyik nem étrendkiegészítö. A helyes válaszok aránya a gyógyszerként forgalomban lévő immunerösítő és vitamin készítménynél volt a legalacsonyabb, $12 \%$ és $52 \%$, tehát első hipotézis többnyire alátámasztást nyert. A megkérdezett diákok 64\%-a szed étrend-kiegészítőt, legtöbbjük alkalmanként. Leggyakrabban saját maguk vásárolnak a terméket. Általában patikában $(92 \%)$, kisebb arányban drogériában, boltban (12\%) is veszik őket, $8 \%$ mindkét helyen vásárol. A gyógyszerformák kiválasztásához a kitöltők hat opciót kaptak, melyből hármat jelölhettek. Összesen 62 jelölés érkezett a 25 fötől, így ez a szám képzi a 100\%-ot. A hat lehetőség közül öt darab a 37/2004 ESZCSM rendelet alapján elfogadott gyógyszerforma, míg egy, a kenőcs és kúp kategória külsőleg alkalmazható, félszilárd gyógyszerforma, mely a kínálat teljessége miatt lett berakva. A második legtöbb szavazat $(19,2 \%)$ erre a kategóriára esett, viszont a bőrt mint beviteli kaput választva már nem beszélhetünk étrend-kiegészítőről. A lista élén a tabletta $(29,0 \%)$ áll, melyet a válaszadók $78 \%$-a bejelölt, igazolva a 3. hipotézist. Harmadik helyen a por, granulátum forma $(17,7 \%)$ helyezkedik el. Majd ezt követi a pezsgőtabletta (14,5\%), a folyadék (11,3\%) és a kapszula $(8,1 \%)$. A készítmény fontosabb jellemzőit egy négyig terjedő skálán vizsgáltuk. Az eredmények alapján fontosnak talált tulajdonságok az ár $(2,86)$, az íz $(2,80)$ és az adagolás $(2,68)$. Míg a méret $(2,40)$, a forma $(1,96)$ a csomagolás $(1,76)$ és a szín $(1,68)$ inkább közömbös számukra. A 2. hipotézis részben teljesült, de az ár szerepe jelentősebb a vártnál. A könnyen bevehető tabletta számukra egyben lenyelhető (68\%) vagy elszopogatható (60\%). Míg a vízben oldhatóságot 48\%-uk találta jó megoldásnak. A legkevésbé értékelt mód a rágótabletta volt (28\%). (1. ábra)

A 11., 12. és 13. kérdés egy tabletta tervezését várta el a kitöltőtől. Melyben az általuk megadható paraméter természetesen a szín, az íz és a forma A megálmodott tabletták $77,27 \%$-a a klasszikus kör alakú tabletta, melynek $29,41 \%$ törővonallal is rendelkezik. 
1. ábra: Bevehetőség megítélése

\section{7) Milyen számodra egy könnyen bevehető tabletta? (Többet is jelölhetsz!)}

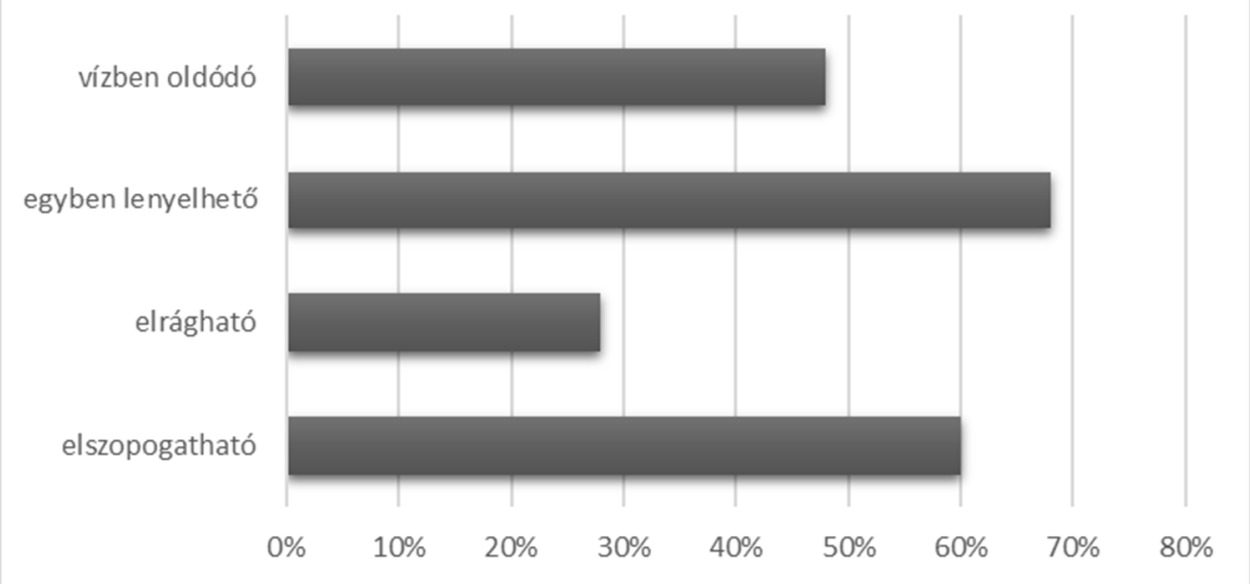

Forrás: A szerző saját szerkesztése (2018)

A színét tekintve kiemelkedik a fehér (68\%) és ezt követi a rózsaszín és a kék (8-8\%) (2. ábra). 68\%-a a tablettáknak rendelkezett valamilyen ízzel. Ezek pedig a $36 \%$ édes, $24 \%$ gyümölcsös, $8 \%$ sós ízből tevődik össze. A kimaradt $32 \%$ értelemszerüen íztelen.

\section{2. ábra: Javasolt szín}

12) Milyen színt javasolsz neki?

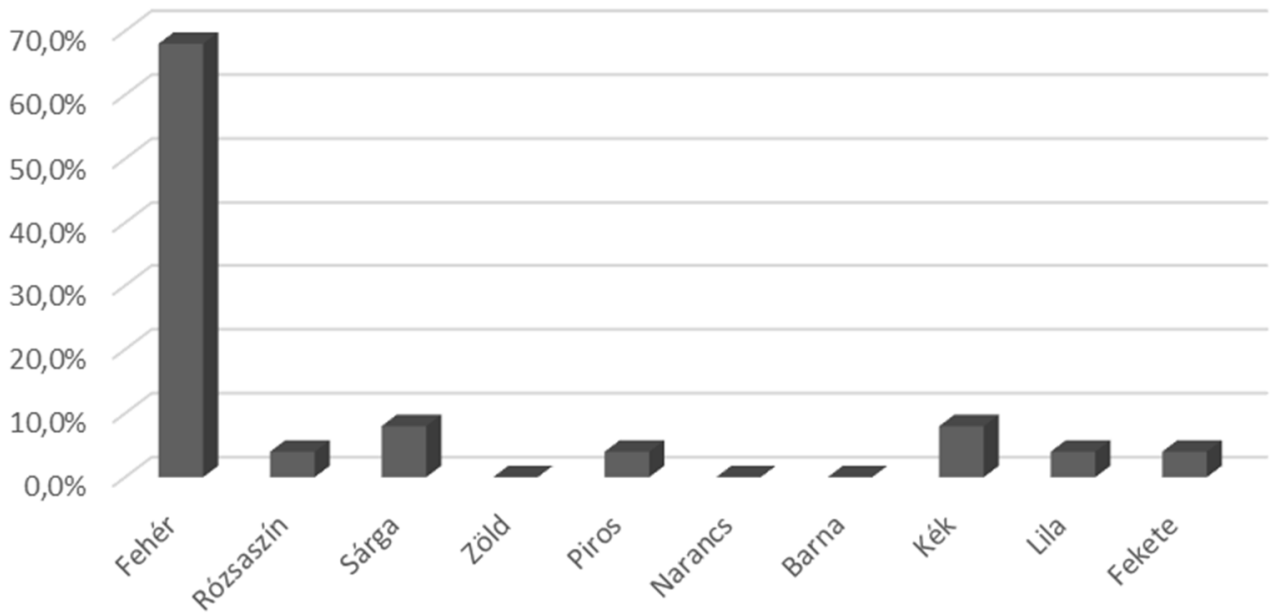

Forrás: A szerző saját szerkesztése (2018) 
A következő feladat a diákok asszociációs képességét hivatott felmérni, hogy adott mintákból milyen hatású készítményre gondolnak. Kiemelkedő adat, hogy a kék színü tablettát az értékelhető választ adók 50\%-a vágyfokozásra használná, ahogy azt a forgalomban lévő ugyancsak kék színủ erektilis diszfunkció kezelésére használt szildenofil tartamú tabletta teszi. A szív alakú mintát az értékelhető válaszok 35\%-a cardiovasculáris betegségek kezelésére, 25\%-a vágyfokozásra és további $25 \%$-a anticonceptivumként használná. A béke jelet $80 \%$-ban mentális problémára alkalmaznák, mint antidepresszáns, anxiolitikum vagy szedatohipnotikum. A pontosabb eredmények érdekében további vizsgálat szükséges, kiküszöbölve a színek közötti különbséget, illetve olyan jelek bevonva, melyek könnyebben köthetők adott indikációkhoz. A 15. és 16. feladat választási lehetőséget kínált mind színben, mind tabletta formában a kitöltőknek. A 10 darab szín közül hármat kellett választani. Itt is, mint a tervezös feladatban is, a fehér szín nyert (21,3\%). Ezt követte a rózsaszín $(14,7 \%)$ és a sárga $(13,3 \%)$. A további színek 4-10\% közötti értékekben szerepelnek. A legkisebb arányt (1,3\%) a fekete kapta. A formákban 12 lehetőség közül választhattak. $41 \%$ valamelyik kör alakú tablettát jelölte. További $23 \%$ valamilyen divatos film, játék, mese alakot választott. $14 \%$ döntött a kemény kapszula mellett, $12 \%$ a lágyzselatin kapszula mellett.

\section{Következtetések, javaslatok}

Az emberek többsége még mindig a patikákban vásárolja az étrend-kiegészítőjét, melyek közül főként az ár alapján tesz különbséget, nem biztos, hogy ismerve a minőségi különbséget két étrend-kiegészítők között, vagy vény nélkül kapható gyógyszer és étrend-kiegészítő között. A vitaminokat, növényi anyagokat tartalmazó készítményeket célszerübb ebben a kategóriában piacra hozni, mivel engedélyezése, ellenőrzése is sokkal olcsóbb a gyártó számára, mely a fogyasztói áron jelentősen meglátszódik. Ez új termék engedélyezése így 50000 Ft, míg gyógyszer kategóriában több milliós költségeket ölelne fel (pl.: klinikai vizsgálatok, a minőségellenőrzés és folyamat-validálás). A további vizsgálat szükséges a fogyasztó ár és minőség közötti összefüggés részletes elemzéséhez, hiszen egy étrend-kiegészítőt is lehet GMP körülmények között gyártani, melyben biztosított az alapanyag és a késztermék minősége is, viszont árban növekedést vonhat maga után. Betegelégedettségi adatok alapján látszik, hogy a tabletta formát érdemes alkalmaznunk, megtartva a kör formát és a fehér szín, cukros bevonást alkalmazva és az árat szem előtt tartva. Ez tökéletes kiindulási terméke lehet egy vállalkozásnak. Viszont a tervezős feladatból látszik, hogy a vevők nem elég kreatívak és ha a 15., 16. feladat alapján opciókat állítunk fel eléjük akkor a döntésük már sokkal jobban szerteágazó lesz. Célszerü tehát a piacot lefedni a különböző ízü, színủ és formájú tablettákkal. A költséget jól csökkentheti, hogy a szilárd gyógyszerformák aránya igen magas volt a preferált formák között, melyet egy gyár kihasználhat és rögtön több gyógyszerformával is piacra léphet. A granulátum, tabletta, pezsgőtabletta, kapszula százalékos szavazati aránya közel $70 \%$ volt, tehát ezek kínálásával a piac széles körben lefedhető. 


\section{Irodalomjegyzék}

Fraser, J. (2012): Solving the Quality by Design Dilemma $<$ https://www.qualitydigest.com/inside/twitter-ed/taking-holistic-approach-qualitydesign.html\#> (2019.03.04.)

Yu, L. X., Amidon, G., Khan, M. A., Hoag, S. W., Polli, J., Raju, G. K., Woodcock, J. (2014): Understanding Pharmaceutical Quality by Design. The AAPS journal, 16 (4): 771-783. <https://www.ncbi.nlm.nih.gov/pmc/articles/PMC4070262/> (2019.03.04.)

Pallagi E., Paál T., Csóka I. (2015): A Quality by Design (QbD) bemutatása és alkalmazási lehetőségeinek ismertetése a nano-rendszerü gyógyszertechnológiai fejlesztésekben. Gyógyszerészet, 59: 387-395.

Charoo N. A., Shamsherb, A. A. A., Zidan, A S., Rahman, Z. (2012): Quality by design approach for formulation development: a case study of dispersible tablets. International Journal of Pharmatceutics, 423 (2): 167-178. <https://scholar.google.hu/scholar?q=Charoo+N.+A.,+et+ al.:+Int.+J.+Pharm.+423,+167-178+(2012).\&hl=hu\&as_sdt=0\&as_vis=1\&oi=scholart\&sa=X\& ved=0ahUKEwirtISGodHZAhUCZ1AKHSGfDSoQgQMIJzAA> (2018.03.04.)

37/2004. (IV. 26.) ESZCSM rendelet az étrend-kiegészítőkről. Hatályos: 2017.01.01-től <http://njt.hu/cgi_bin/njt_doc.cgi?docid=84229.333634> (2019.03.04.) 